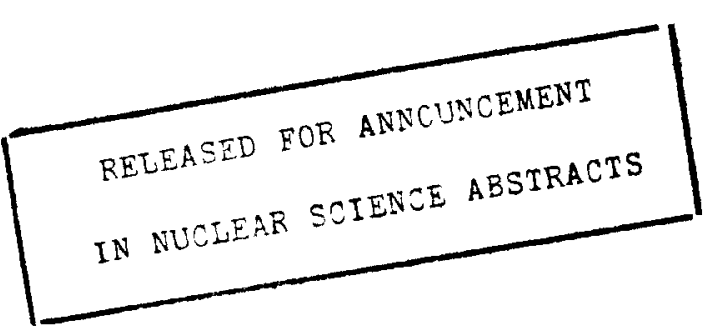

ELECTROLYTIC PREPARATION OF URANOUS NITRATE

by

G. Starr Nichols

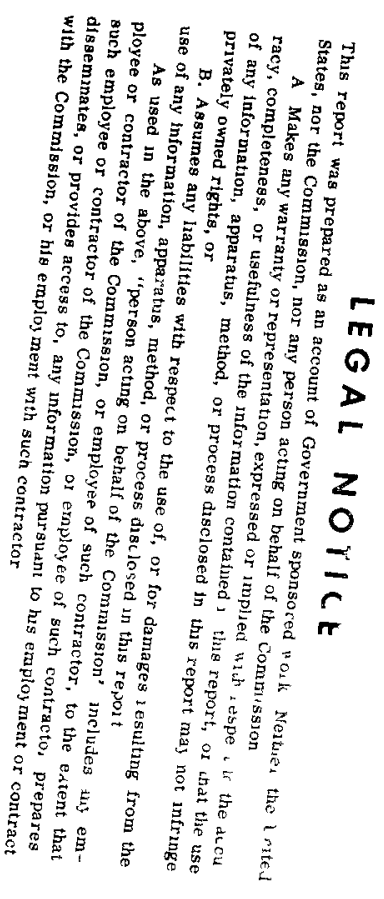

Approved by

D. S. Webster, Research Manager Separations Engineering Division

August 1966
Chemlcal Separations Processes

for PIutonium and Uranium

(TID-4500)

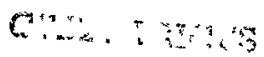

H.C. $\$ 1.00$

\author{
E. I. DU PONT DE NEMOURS \& COMPANY \\ SAVANNAH RIVER LABORATORY \\ AIKEN, S. C. 29801 \\ CONTRACT AT(07.2)-1 WITH THE
}

UNITED STATES ATOMIC ENERGY COMMISSION 


\section{DISCLAIMER}

This report was prepared as an account of work sponsored by an agency of the United States Government. Neither the United States Government nor any agency Thereof, nor any of their employees, makes any warranty, express or implied, or assumes any legal liability or responsibility for the accuracy, completeness, or usefulness of any information, apparatus, product, or process disclosed, or represents that its use would not infringe privately owned rights. Reference herein to any specific commercial product, process, or service by trade name, trademark, manufacturer, or otherwise does not necessarily constitute or imply its endorsement, recommendation, or favoring by the United States Government or any agency thereof. The views and opinions of authors expressed herein do not necessarily state or reflect those of the United States Government or any agency thereof. 


\section{DISCLAIMER}

Portions of this document may be illegible in electronic image products. Images are produced from the best available original document. 


\begin{abstract}
Laboratory and semiworks electrochemical converters for producing uranous nitrate from uranyl nitrate were designed and operated. The laboratory unit, with a porous separator between cathode and anode, gave good performance. A suitable separator was not available for the semiworks unit, so a simple recirculation design was used to produce sufficient uranous nitrate for testing as a plutonium reductant in the plant. The performance of this design was poor because of oxidation at the anode of both uranous ion and the hydrazine used as stabilizer.
\end{abstract}




\section{CONTENTS}

Page

List of Tables and Figures. . . . . . . . . . . . . 1v Introduction . . . . . . . . . . . . . . . . . 1

Summary . . . . . . . . . . . . . . . . . . . . 1

Description of Apparatus . . . . . . . . . . . . 3

Laboratory . . . . . . . . . . . . . . . 3

Semiworks . . . . . . . . . . . . . . . . 4

Procedure and Results . . . . . . . . . . . . . 6

Laboratory . . . . . . . . . . . . . . 6

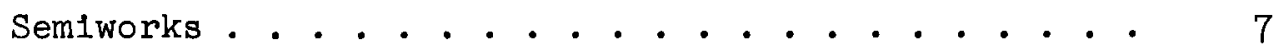

Current Utilization . . . . . . . . . . . . . . 8

Hydrazine Consumption . . • . . . . . . . . . . . . 9

References . . . . . . . . . . . . . . . . . . . 12 


\section{LIST OF TABLES AND FIGURES}

Table

$\underline{\text { Page }}$

I Data From Laboratory Converter........ 6

II Data From Semiworks Converter . . . . . . 8

III Hydrazine Consumption in Both Converters.... 10

IV Electrochemical Reactions at the Cathode . . . 11

\section{Figure}

1 Laboratory-Scale Converter for Producing

Uranous Nitrate . . . . . . . . . . . . 3

2 Semiworks Converter for Producing Uranous Nitrate . . . . . . . . . . 4

3 Deta1ls of Electrodes for Sem1works Converter . 5

4 Typical Production Data for Semiworks and Laboratory Converters . . . . . . . . 7

5 Current Utilization in Semiworks and Laboratory Converters . . . . . . . . . 9

6 Hydrazine Consumption in the Semiworks Converter . . . . . . . . . . . . . . . 


\title{
ELECTROLYTIC PREPARATION OF URANOUS NITRATE
}

\author{
INTRODUCTION
}

Plutonium is separated from uranium in both the first and second cycles of the Purex solvent extraction process by reducing the piutonium ion to a water-soluble valence state and leaving the uranium in an organic-soluble valence state. This selective reduction is accomplished by adding ferrous ion and a stabilizer, such as sulfamic acid, to the aqueous stream entering the partition section of the mixer-settlers. An equally effective reductant is uranous ion, $U(I V)$, which is converted to urany ion, $U(V I)$, in the mixer-settler and thus extracted into the solvent. $U(I V)$ has an advantage over ferrous ion in that $1 t$ does not leave solids in the aqueous stream to limit the evaporative removal of nitric acld before neutralization and storage of the residue.

$\mathrm{U}(\mathrm{IV})$ is preferred as the nitrate because it adds no new anions to the waste evaporator residues. However, a nitric acid system oxidizes $U(I V)$ to $U(V I)$, so that the route to $U(I V)$ is difficult and the product must be stablized by hydrazine for storage and use. Electrochemical, (1) chemical, (a) photochemical, (3) and catalytic hydrogenation ${ }^{(4)}$ methods can each prepare uranous nitrate free of other anions and cations. These methods have been reviewed by Katz. (5) The electrochemical method was chosen for the work reported here because a singlestep electrolysis can produce high concentrations of uranous nitrate with, theoretically, only a small addition of stabilizer. Uranyl nitrate from the solvent extraction plant can be used as feed for a large electrolytic cell, with recycle of about $2 \%$ of the throughput uranium to supply a reductant for plutonium. This report discusses laboratory tests, the assembly of plant-size equipment, and the production of test amounts of uranous nitrate by electrolytic reduction of uranyl nitrate.

\section{SUMMARY}

A small laboratory cell was built to test the electrochemical production of uranous nitrate from uranyl nitrate. The cell was comprised of a cylindrical niobium cathode surrounded by a tantalum anode; the electrodes were separated by a thinwalled crucible of porous aluminum oxide. The cell was charged with a solution of $1.15 \mathrm{M}$ uranyl nitrate and $6 \mathrm{M}$ nitric acid; the cathode compartment was made $0.38 \mathrm{M}$ in hydrazine to stabilize the uranous ion produced. At a current density of $600 \mathrm{amp} / \mathrm{ft}^{2}$, a uranous ion concentration of $0.85 \mathrm{M}$ was attained with an average current efficiency of $60 \%$ and a drop of $0.15 \mathrm{M}$ in the hydrazine concentration. 
Although the performance of the laboratory cell was good, a similar design for a semiworks unit was not attempted because a diaphragm material could not be obta1ned with suitable permeab1lity, strength, and chemical resistance. Instead, titanium plates were stacked closely together to form six cells through which was circulated a solution of $1.35 \mathrm{M}$ uranyl nitrate and $1.7 \mathrm{M}$ nitric acid, maintained at $0.3 \mathrm{M}$ hydrazine. The liquid moved in parallel through the cells; the electric current in series. Recirculation limited the U(IV) concentration to a maximum of $0.5 \mathrm{M}$ by allowing oxidation of a portion at the anode during each passage. The best performance was obtained by taking the U(IV) concentration to only 0.35M. Even then, the a verage current efficiency at $800 \mathrm{amp} / \mathrm{ft}^{2}$ was only $33 \%$, and 1.8 moles of hydrazine per mole of $U(I V)$ produced was consumed by oxygen liberated at the anode.

Desplte this poor performance, 400 gallons of solution was converted to $0.35 \mathrm{M}$ uranous nitrate at a rate of $70 \mathrm{lb} / \mathrm{hr}$. 


\section{LABORATORY}

The laboratory unit (Figure 1) was of a concentric cylindrical design, with a niobium cathode surrounding a sintered (porous) aluminum oxide crucible and a tantalum anode. Circulation at the cathode surface was provided by an external pump of $2 \mathrm{gpm}$ capacity. The circulating system contained a heat exchanger to control the temperature of the catholyte. In contrast, heating of the anolyte was not controlled, so the current was limited by onset of bolling in the anolyte.

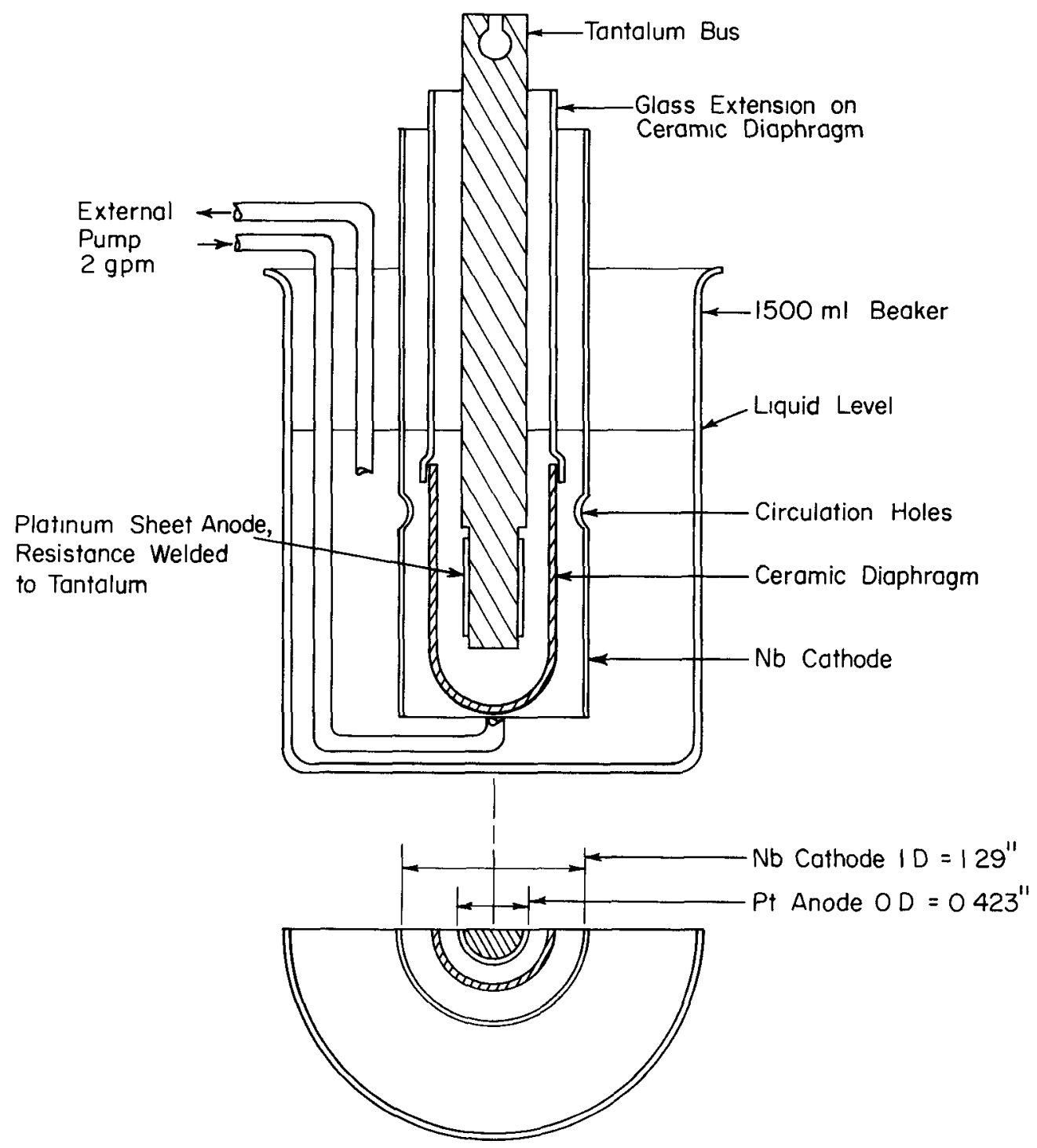

FIG. I LABORATORY - SCALE CONVERTER FOR PRODUCING URANOUS NITRATE 


\section{SEMIWORKS}

The semiworks converter, shown in Figures 2 and 3 , contalned seven titanium electrodes stacked in a compact bundle to form six cells. The cells were in series electrical flow and in parallel hydraulic flow. The anode side of each titanium plate was clad with platinum. The electrodes were 4 feet tall by 16 inches wide ( 15 inches active width), maintained 1/8-inch apart with washers and rods of $G-7^{*}$ plastic. The two outside electrodes were of thick (7/8-inch) titanium for structural reasons. The long, vertical edges of the electrodes were spaced

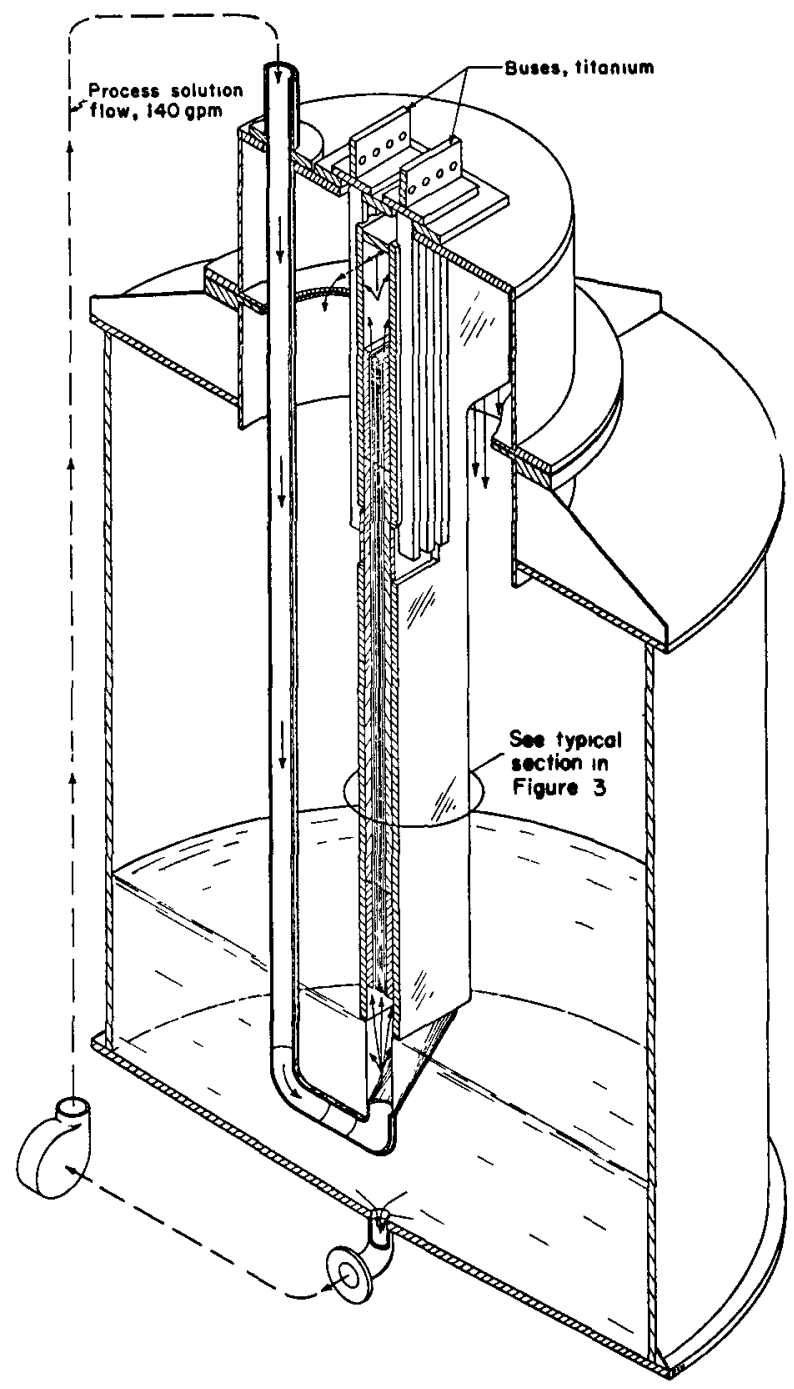

FIG. 2 SEMIWORKS CONVERTER FOR PRODUCING URANOUS NITRATE (Installed in 1200 -gallon stainless steel tank)

* G-7 is a trade name applied to a glass fiber-silicone rubber laminate produced by the General Electric Company, Schenectady, N. Y. 


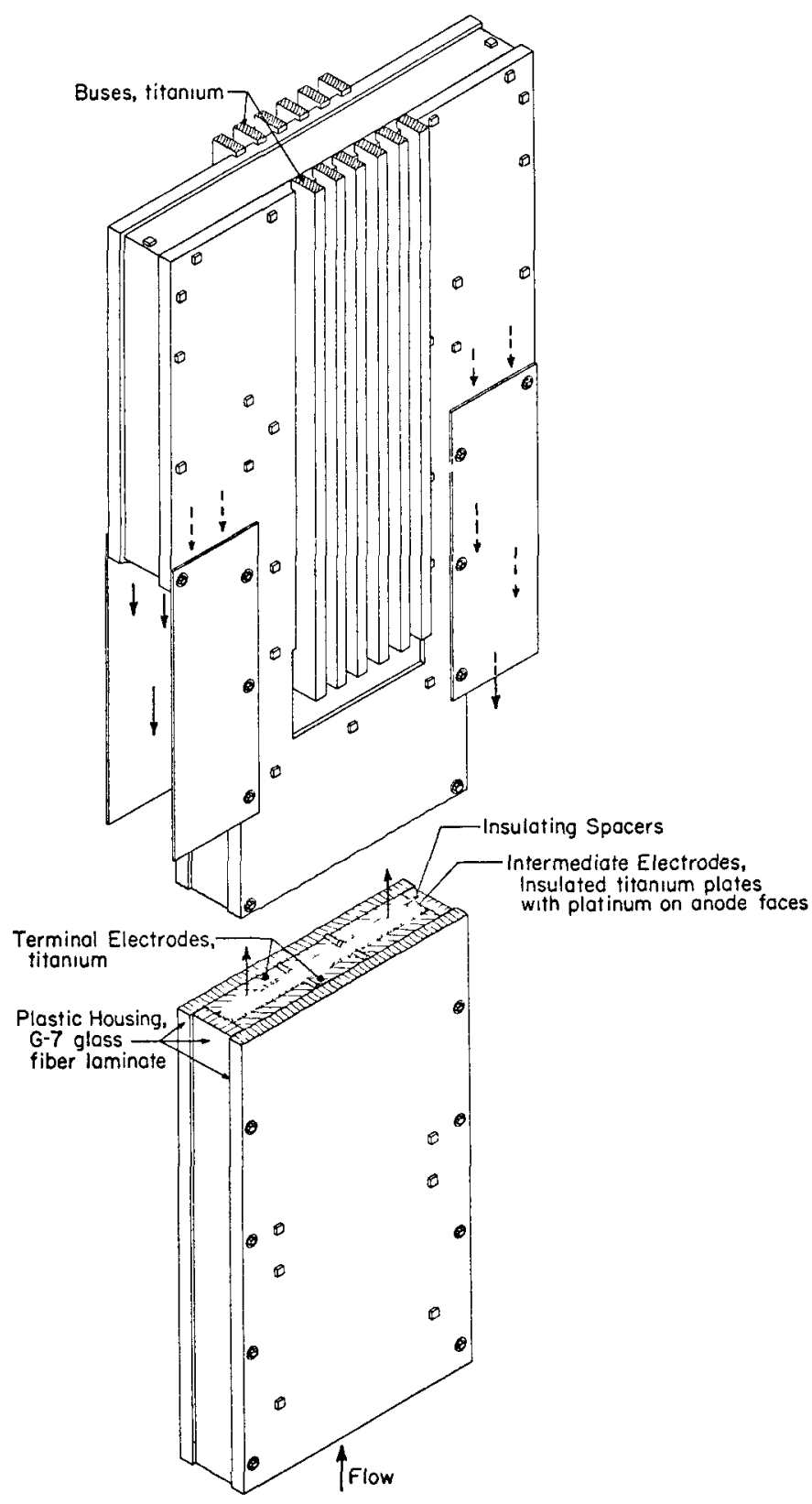

FIG. 3 DETAILS OF ELECTRODES FOR SEMIWORKS CONVERTER

by $1 / 2-1$ nch-wide strips of $1 / 8$-inch $\mathrm{G}-7$. At both top and bottom the titanium plates were held in place by butting them against G-7 plates 12 inches high and 16 inches wide, and of a thickness to match the titanium. The entire assembly was enclosed in a box of 3/4-inch-thick G-7, fastened with stainless steel bolts. The massive titanium plates on both sides of the bundle were connected to titanium bus bars which extended through large holes in the G-7 shell and through the top of the tank, where they connected to flexible copper cables. 
In operation, the feed solution was pumped at $150 \mathrm{gpm}$ from the supporting tank, through a heat exchanger, and into the bottom of the electrode assembly. The liquid overflowed from the assembly into the tank and mixed with the original feed solution.

PROCEDURE AND RESULTS

\section{LABORATORY}

The performance that can be obtained by isolating cathode and anode solutions with a porous diaphragm is illustrated by the laboratory converter. The unit was charged with 1.32 liters of solution containing $1.15 \mathrm{M}$ uranyl nitrate, $6.0 \mathrm{M} \mathrm{HNO}_{3}$, and (in the cathode compartment) $0.38 \mathrm{M}$ hydrazine. The current was maintained at 20 amperes throughout the run and samples of solution were removed for analysis at half-hour intervals. No adjustments of concentrations were made. The resulting data, presented in Table I, were used to construct the middle curve of the three smoothed curves in Figure 4 showing U(IV) concentration as a function of amp-hr-cells per liter. As is apparent from the curve, the conversion approaches completion.

\section{$\underline{T A B L E}$ I}

Data from Laboratory Converter

$$
\begin{aligned}
& 0.034 \mathrm{ft}^{2} \text {, area of cathode } \quad 1.3211 \text { ters at } 45^{\circ} \mathrm{C} \\
& 1 \text { cell } 275 \mathrm{~g} \mathrm{U} / I \text { (1.15M), In1t1aI U(VI) } \\
& \text { conc. } \\
& 0.6 \mathrm{ft} / \mathrm{sec} \text { liquid velocity } 6.0 \mathrm{M} \mathrm{HNO}_{3} \text {, initlal conc. } \\
& \text { Porous ceramic separator } \quad 0.38 \mathrm{M} \text { Hydrazine, Initial conc. } \\
& \text { (in cathode only) }
\end{aligned}
$$

\begin{tabular}{|c|c|c|c|c|}
\hline $\begin{array}{c}\text { Time } \\
\text { from start, } \\
\mathrm{hr} \\
\end{array}$ & $\begin{array}{l}\text { Current, } \\
\text { amp }\end{array}$ & $\begin{array}{l}\text { Amp-hr-cells } \\
\text { per liter }\end{array}$ & $\begin{array}{c}U(I V), \\
g / I\end{array}$ & $\begin{array}{c}\text { Integrated } \\
\text { Current Eff'y, } \\
\text { of Theor U(IV) }\end{array}$ \\
\hline 0.5 & 20.0 & 7.6 & 23.8 & 70 \\
\hline 1.0 & 20.0 & 15.1 & 49.0 & 73 \\
\hline 1.5 & 20.0 & 22.7 & 74.8 & 74 \\
\hline 2.0 & 20.0 & 30.4 & 100 & 74 \\
\hline 2.5 & 20.0 & 37.9 & 123 & 73 \\
\hline 3.0 & 20.3 & 46.2 & 146 & 71 \\
\hline 3.5 & 20.2 & 53.6 & 163 & 68 \\
\hline 4.0 & 20.2 & 61.3 & 179 & 66 \\
\hline 4.5 & 20.1 & 68.6 & 192 & 63 \\
\hline 5.0 & 20.1 & 76.2 & 204 & 60 \\
\hline 5.25 & 19.9 & 79.3 & 209 & 59 \\
\hline
\end{tabular}




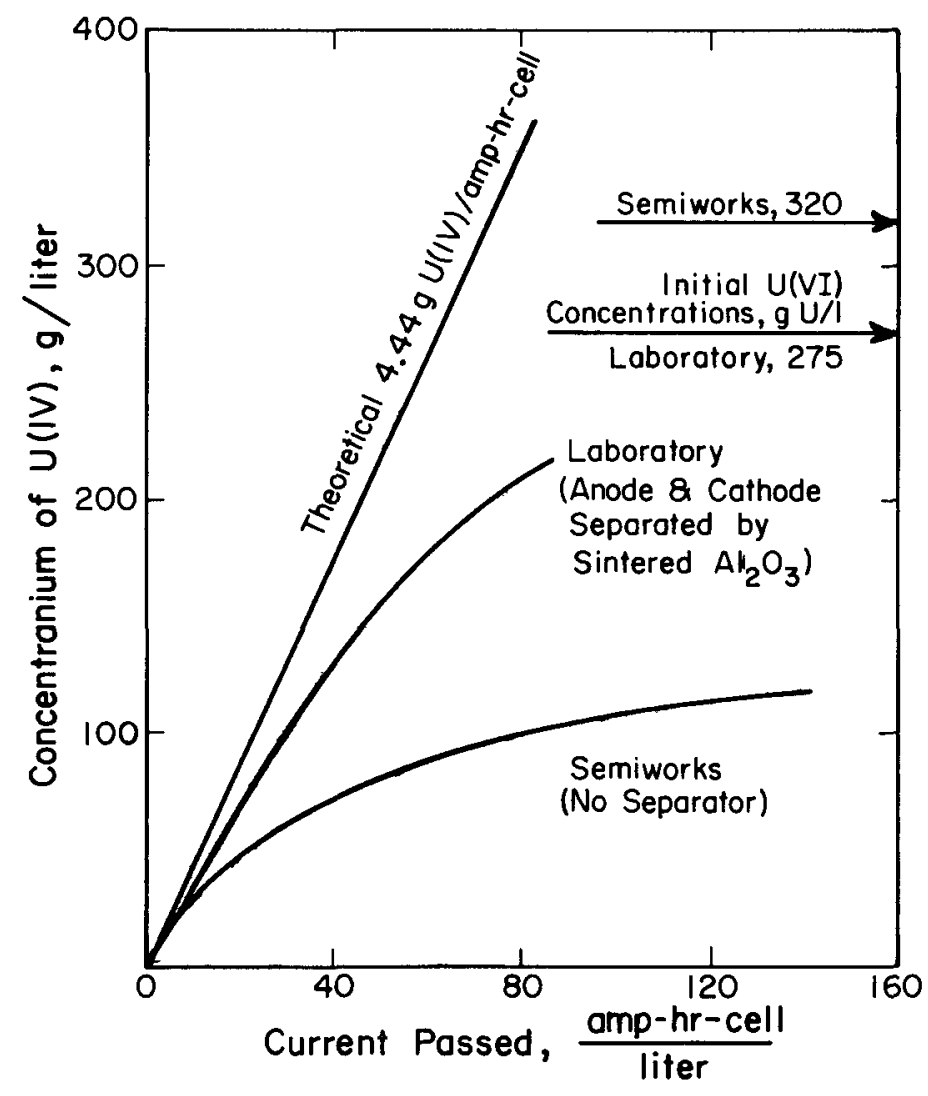

FIG. 4 TYPICAL PRODUCTION DATA FOR SEMIWORKS AND LABORATORY CONVERTERS

\section{SEMIWORKS}

The semlworks converter was charged w1th 400 gallons of $1.35 \mathrm{M}$ uranyl nitrate solution which was $1.7 \mathrm{M}$ in $\mathrm{nitric}$ acid and $0.3 \mathrm{M}$ in hydrazine. The current was maintained at 4000 amperes (required 21 volts) for the first 3 hours, and then was dropped to 2500 amperes for an additional 8 hours. The solution was sampled periodically for analysis for U(IV), $\mathrm{HNO}_{3}$, and $\mathrm{N}_{2} \mathrm{H}_{4}$, and was adjusted each time back to the initial concentrations of $\mathrm{HNO}_{3}$ and $\mathrm{N}_{2} \mathrm{H}_{4}$ by appropriate additions. The data, presented in Table II, were used to construct the lowest of the smoothed curves in Figure 4. It is apparent that the performance is poor, with conversion leveling off at about $0.5 \mathrm{M} \mathrm{U}(\mathrm{IV})(120 \mathrm{~g} / \mathrm{l})$ out of a potential of 1.35M. Nevertheless, during the first 4 hours of operation ( 57.5 amp-hr-cells per 11ter), conversion proceeded at an average rate of 70 pounds $U$ per hour to a concentration of about $0.35 \mathrm{M}$ $\mathrm{U}(\mathrm{IV})(82 \mathrm{~g} / \mathrm{I})$. Seventy pounds per hour is adequate to supply reducing capacity equivalent to the consumption of ferrous sulfamate in the separations plant. 
TABLE II

Data from Semiworks Converter
$5 \mathrm{ft}^{2}$, area of each electrode
$400 \mathrm{gal}$
$50^{\circ} \mathrm{C}$
6 cells in series
$320 \mathrm{~g} \mathrm{U} / 1(1.35 \mathrm{M})$, inftial
$\mathrm{U}(\mathrm{VI})$ conc.
$0.4 \mathrm{ft} / \mathrm{sec}$ liquid veloc1ty
1. $7 \mathrm{M} \mathrm{HNO} \mathrm{HN}_{3}$ maintained by addition
0.3 M Hydrazine " " "

\begin{tabular}{|c|c|c|c|c|c|}
\hline $\begin{array}{c}\text { Time } \\
\text { from start, } \\
\text { hr }\end{array}$ & $\begin{array}{l}\text { Current, } \\
\text { amp }\end{array}$ & $\begin{array}{l}\text { Amp-hr-cells } \\
\text { per liter }\end{array}$ & $\begin{array}{c}U(I V), \\
g / 1\end{array}$ & $\begin{array}{c}\mathrm{N}_{2} \mathrm{H}_{4} \\
\text { Consumption, } \\
\text { g-moles }\end{array}$ & $\begin{array}{c}\text { Integrated } \\
\text { Current Eff'y, } \\
\text { of of Theor U(IV) }\end{array}$ \\
\hline 1 & 4000 & 16 & 39 & 290 & 55 \\
\hline 3 & 4000 & 48 & 76 & 750 & 36 \\
\hline 5 & 2500 & 67 & 88 & 1220 & 30 \\
\hline 7 & 2500 & 87 & 104 & 1470 & 27 \\
\hline 9 & 2500 & 107 & 108 & 1850 & 23 \\
\hline 11 & 2500 & 127 & 113 & 2200 & 20 \\
\hline
\end{tabular}

\section{CURRENT UTILIZATION}

Instantaneous current utilizations for each cell were obtained by measuring the slope at several places along smoothed curves of the type appearing in F1gure 4, and ratioing to the slope of the line for the theoretical conversion. The resulting utilizations are shown in Figure 5 as functions of the fraction of $U(V I)$ converted to $U(I V)$. Current utilization for both units started at about $70 \%$, presumably indicating the same mixture of electrode reactions under starting conditions. Similar electrode reactions are reasonable because current densities, hence electrode potentials, were similar: $800 \mathrm{amp} / \mathrm{ft}^{2}$ for the large unit, and $600 \mathrm{amp} / \mathrm{ft}^{2}$ for the small unit. Current utilization fell rapidiy in the semiworks converter as $U(I V)$ built up in solution, was recirculated past both cathode and anode, and a portion was reoxidized at the anode; utilization extrapolated to zero at about 0.4 conversion of the uranium. In contrast, current utilization in the laboratory unit rose slightly to a maximum at about 0.2 of the U(VI) converted, then fell slowly toward zero utilization as complete conversion was approached. 


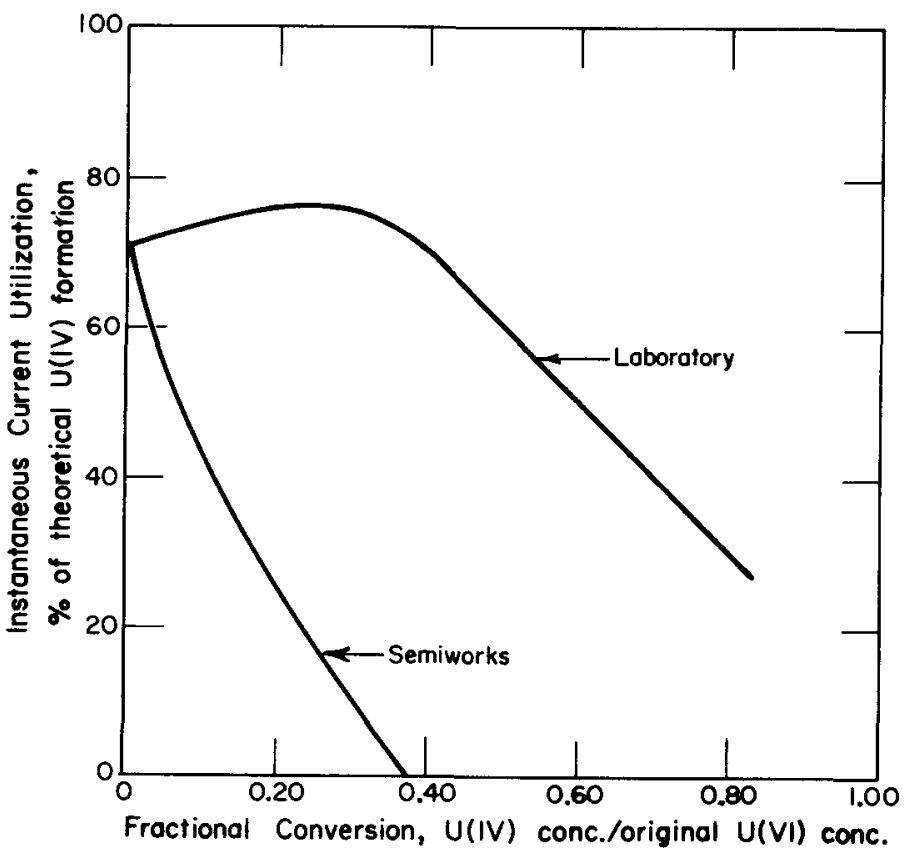

FIG. 5 CURRENT UTILIZATION IN SEMIWORKS AND LABORATORY CONVERTERS

\section{HYDRAZINE CONSUMPTION}

Hydrazine was consumed in both converters, although at a much higher rate in the semiworks design. The hydrazine usage from Table II for the semiworks unit is presented in Figure 6 as a function of the faradays of current passed. The straight line through the data means that consumption is proportional to amp-hr-cells and is essentially independent of the U(IV) concentration or the current density, both of which changed during the run. The line indicates a consumption of 0.306 mole $\mathrm{N}_{2} \mathrm{H}_{4}$ per faraday of current passed.

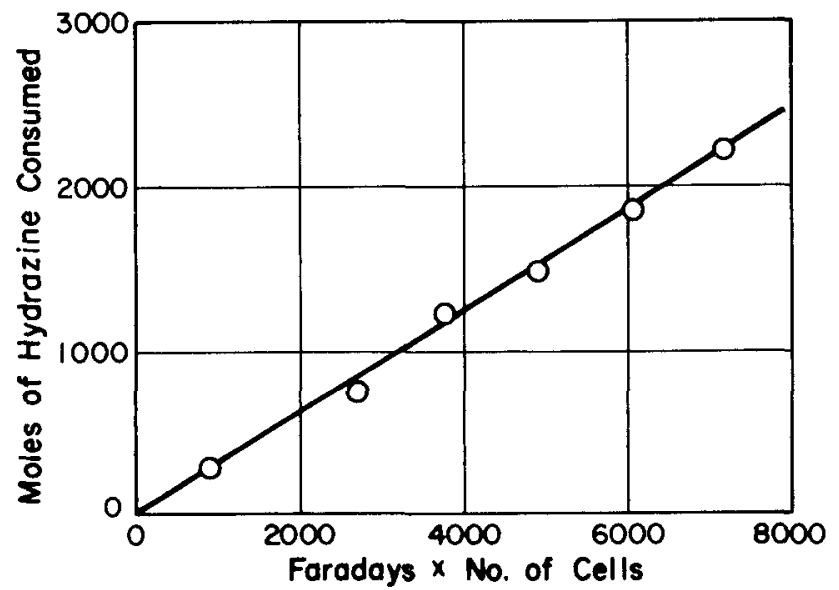

FIG. 6 HYDRAZINE CONSUMPTION IN THE SEMIWORKS CONVERTER 
In the laboratory unit, hydrazine was present only in the cathode compartment. Depletion was relatively slight (Table III), and again the rate was independent of $U(I V)$ concentration. The data in Table III, however, indicate that consumption in the cathode compartment may be proportional to current density; this small effect is apparently obscured in the semiworks unit by the much larger consumption at the anode.

\section{TABLE III}

\section{Hydrazine Consumption in Both Converters}

\begin{tabular}{|c|c|c|c|}
\hline Type of Cell & $\begin{array}{l}\text { Current } \\
\text { Density, } \\
\text { amp/ft? }\end{array}$ & $\begin{array}{l}\text { Final U(IV) } \\
\text { Conc, } \mathrm{M}\end{array}$ & $\begin{array}{c}\mathrm{N}_{2} \mathrm{H}_{4} \text { Consumption, } \\
\text { mole/faraday }\end{array}$ \\
\hline $\begin{array}{l}\text { Laboratory } \\
\text { (Porous } \\
\text { dlaphragm) }\end{array}$ & $\begin{array}{l}710 \\
710 \\
710 \\
710\end{array}$ & $\begin{array}{l}0.42 \\
0.53 \\
0.77 \\
0.80\end{array}$ & $\begin{array}{l}0.049 \\
0.059 \\
0.056 \\
0.061\end{array}$ \\
\hline & 350 & 0.97 & 0.028 \\
\hline Semiworks & 800 to 500 & 0.35 & 0.306 \\
\hline
\end{tabular}

When the average $\mathrm{N}_{2} \mathrm{H}_{4}$ consumption in the cathode compartment of the laboratory unit $\{0.056$ mole/faraday) is subtracted from the total consumption in the semiworks unit $(0.306 \mathrm{~mole} /$ faraday), the remaining 0.25 can be attributed to destruction at the anode. Because $0.25 \mathrm{~mole} /$ faraday is exactly equivalent to the rate of formation of oxygen at the anode, it is concluded that hydrazine disappears at the anode by reaction with oxygen.

Disappearance of hydrazine at the cathode is by reaction w1 th $\mathrm{NO}_{2}{ }^{-}$formed as a minor product at the cathode. The pertinent electrochemical reactions at the cathode, and the corresponding standard potentials, are given in Table IV. The standard potentials are only a guide to the relative importance of the reactions. That $1 \mathrm{~s}, \mathrm{UO}_{2}{ }^{2+}$ is most easily reduced, $\mathrm{H}^{+}$is next, and $\mathrm{NO}_{3}{ }^{-}$is the most difficult. At the practical current densities used in these experiments, the rate of diffusion of uranyl ion from the bulk of solution to the cathode is not fast enough to carry all the current, so the cathode becomes sufficientiy negative to inftiate one or more of the other reactions. The fact that hydrazine is depleted at the cathode implies that $\mathrm{NO}_{2}^{-}$is being generated and reacting with the hydrazine, and hence that at least the first three electrode reactions are active. 
Electrochemical Reactions at the Cathode

$\underline{E_{0} \text {, volts }}$

$$
\begin{array}{llc}
\mathrm{UO}_{2}^{2+}+2 \mathrm{e}^{-}+4 \mathrm{H}^{+} \rightarrow \mathrm{U}^{+4}+2 \mathrm{H}_{2} \mathrm{O} & +0.33 \\
\mathrm{H}^{+}+2 \mathrm{e}^{-}+\mathrm{H}^{+} \rightarrow \mathrm{H}_{2} & 0 \\
\mathrm{NO}_{3}^{-}+2 \mathrm{e}^{-}+2 \mathrm{H}^{+} \rightarrow \mathrm{NO}_{2}^{-}+\mathrm{H}_{2} \mathrm{O} & -0.94 \\
\mathrm{NO}_{3}^{-}+8 \mathrm{e}^{-}+1 \mathrm{OH}^{+} \rightarrow \mathrm{NH}_{4}^{+}+3 \mathrm{H}_{2} \mathrm{O} & -1.30
\end{array}
$$

Nitrite ion oxidizes $U(I V)$ by an autocatalytic mechanism involving nitrate. The hydrazine is present to prevent this oxidation by removing the nitrite. On a few occasions the hydrazine concentration in the laboratory unit was allowed to approach zero, whereupon reversion of the ent1re batch of U(IV) to uranyl Ion occurred, accompanied by evolution of oxides of nitrogen and pronounced foaming. 


\section{REFERENCES}

1. W. E. Harris and I. M. Kolthoff. "The Polarography of Uranium. I. Reduction in Moderately Acld Solutions. Polarographic Determination of Uranium." J. Am. Chem. Soc. 67, 1484 (1945).

2. R. S. Ondrejcin. Preparation of Uranium IV Nitrate Solutions. USAEC Report DP-602, E. I. du Pont de Nemours \& Co., Savannah River Laboratory, Aiken, South Carolina (1961).

3. J. L. Carroll, R. E. Burns, and H. D. Warren. The Photoactivated Reduction of Uranium (VI) to Uranium (IV) Nitrate. USAEC Report HW-70543, General Electric Company, Hanford Atomic Products Operation, Richland, Washington (1961).

4. R. De Leone, G. Cogliati, L. Lorenzini, and R. Lang. "Studies of U(IV) Nitrate." Third Annual Chemical Conference, Gatlinburg, Tennessee, October 9-11, 1962.

5. H. Katz. Some Methods of Preparing Tetravalent Uranium Solutions. USAEC Report BNL-691, Brookhaven National Laboratory, Upton, New York (1961). 